\title{
Vegetasi Riparian Kawasan Sub-DAS Sungai Gajah Wong Yogyakarta
}

\author{
Iis Sholikhati ${ }^{1}$, Tri Retnaningsih Soeprobowati², dan' Jumari ${ }^{3}$ \\ ${ }^{1}$ Mahasiswa Magister Biologi, Universitas Diponegoro \\ 2 Departemen Biologi Universitas Diponegoro; e-mail: trsoeprobowati@live.undip.ac.id \\ ${ }^{3}$ Sekolah Pascasarjana Universitas Diponegoro
}

\begin{abstract}
ABSTRAK
Perubahan lahan memberi dampak pada pengurangan kapasitas resapan khususnya pada riparian sungai yaitu berupa berkurang bahkan hilangnya vegetasi. yang seharusnya menjadi daerah resapan air dan tempat hidup tumbuhan riparian. Dampak ekologi dari berkurangnya vegetasi riparian dapat terjadinya risiko banjir. Jenis vegetasi yang dominan di suatu lokasi dapat dilihat dengan mengetahui nilai tertinggi INP serta keberadaan spesies tumbuhan dilihat dari keanekaragaman suatu vegetasi riparian. Metode yang digunakan metode plot kuadrat. Caranya dengan menmbuat garis transek sepanjang $150 \mathrm{~m}$ yang dibagi menjadi tiga plot kuadrat, dengan jarak antar plot $40 \mathrm{~m}$. Tiap titik tersebut diletakkan plot kuadrat berukuran $10 \mathrm{~m}$ x 10m untuk pohon, $5 \mathrm{~m}$ x $5 \mathrm{~m}$ untuk perdu, dan $1 \mathrm{~m} \times 1 \mathrm{~m}$ untuk herba. Analisis vegetasi, meliputi : kerapatan, dominansi, dan frekuensi. Penelitian dilakukan di kawasan Sub-DAS Sungai Gajah Wong. Hasil dan pembahasan Penelitian ini berupa ditemukan 49 jenis tumbuhan. Spesies tumbuhan yang ditemukan pada habitus pohon terdiri 13 famili. Habitus perdu terdiri 12 famili, dan habitus terdiri herba 12 famili. INP tertinggi pada habitus pohon didominasi oleh jenis bambu. INP tertinggi pada habitus perdu didominasi oleh Mimosa pudica yang hampir pada setiap daerah hulu, tengah dan hilir ditemukan, sedangkan INP habitus herba berupa gulma. Perbedaan indeks keanekaragaman ( $\left.\mathrm{H}^{\prime}\right)$ habitus pohon, perdu dan herba disebabkan oleh berkurang atau bahkan menghilangnya vegetasi akibat perubahan lahan mempengaruhi pola persebaran vegetasi riparian.
\end{abstract}

Kata kunci : Vegetasi Riparian, Sub -DAS Sungai Gajah Wong, Yogyakarta, Hargobinangun, Kanggotan

\begin{abstract}
Land changes have an impact on reducing the absorption capacity, especially in riparian rivers, in the form of reduced or even loss of vegetation. which should be a water catchment area and a habitat for riparian plants. The ecological impact of reduced riparian vegetation can result in the risk of flooding. The dominant vegetation type in a location can be seen by knowing the highest IVI value and the presence of plant species seen from the diversity of riparian vegetation. The method used is the quadratic plot method. You do this by making a $150 \mathrm{~m}$ long transect line divided into three quadratic plots, with a distance between the plots of $40 \mathrm{~m}$. Each of these points is placed a square plot measuring $10 \mathrm{~m} \times 10 \mathrm{~m}$ for trees, $5 \mathrm{~m} \times 5 \mathrm{~m}$ for shrubs, and $1 \mathrm{~m} \times 1 \mathrm{~m}$ for trees. herb. Vegetation analysis, including: density, dominance, and frequency. The research was conducted in the Gajah Wong River sub-watershed area. Results and discussion of this study found 49 types of plants. The plant species found in tree habitus consist of 13 families. Shrub habitus consists of 12 families, and herbal habitus consists of 12 families. The highest Index value in tree habitus is dominated by bamboo species. The highest index value in shrub habitus was dominated by Mimosa pudica which is found in almost every upstream, middle and downstream area, while index value of herbal habitus is in the form of weeds. The difference in the diversity index ( $\mathrm{H}$ ') of tree, shrub and herbaceous habitats is caused by reduced or even loss of vegetation due to land changes affecting the distribution pattern of riparian vegetation.
\end{abstract}

Keyword : Riparian vegetation, Gajah Wong Yogyakarta sub - watershed, Yogyakarta, Hargobinangun, Kanggotan

Citation: Sholikhati, I., Soeprobowati, T.R., dan Jumari. (2020). Vegetasi Riparian Kawasan Sub-DAS Sungai Gajah Wong, Yogyakarta.Jurnal Ilmu Lingkungan, 18(2), 401-410, doi:10.14710/jil.18.2.401-410

\section{Pendahuluan}

Daerah Istimewa Yogyakarta merupakan salah satu provinsi di Indonesia yang memiliki banyak sungai. Beberapa sungai melewati daerah permukiman dengan penduduk yang padat yaitu Sungai Code, Sungai Gajah Wong, dan Sungai Winongo. Sungai - sungai tersebut mengalir melewati tengah - tengah Yogyakarta yang menjadi pusat aktivitas penduduk (Sriyono dan Kresnanto, 2017).

Salah satu sungai di Daerah Istimewa Yogyakarta yang mengalami alih fungsi lahan adalah Sub-DAS Sungai Gajah Wong. Sub - DAS Sungai Gajah Wong memiliki sungai utama yaitu sungai Gajah Wong. 
Sholikhati, I., Soeprobowati, T.R., dan Jumari. (2020). Vegetasi Riparian Kawasan Sub-DAS Sungai Gajah Wong, Yogyakarta.Jurnal IImu Lingkungan, 18(2), 401-410, doi:10.14710/jil.18.2.401-410

Aliran sungai tersebut melintasi Kab. Sleman, Kota Yogyakarta, dan Kab. Bantul (BPS, 2017).

Aliran dari Sungai Gajah Wong mengalir dari lereng Gunung Merapi di sebelah utara dan bertemu dengan Sungai Opak di sebelah selatan. Sungai Gajah Wong melewati kawasan pedesaan, dan pertanian di Kabupaten Sleman, kemudian pemukiman penduduk perkotaan, industri rumah tangga di Kota Yogyakarta, serta kawasan pertanian, perikanan dan pemukiman di Kabupaten Bantul (Djumanto, 2013).

Sungai tersebut melewati lokasi yang strategis sehingga menjadi incaran bagi para penduduk, selain itu, lahan ditepi sungai pun jauh lebih terjangkau sehingga banyak penduduk yang memiliki minat membangun bangunan di tepi sungai untuk menjadi tempat tinggalnya.

Larangan mendirikan bangunan didalam atau yang melintas sungai diatur oleh PP Nomor 38 Pasal 22 Tahun 2011 dan hanya dapat dilakukan memperoleh izin dari pejabat yang berwenang, terutama di sekitar bantaran sungai, yang termasuk dalam garis sempadan yaitu garis batas luar pengaman sungai (Peraturan Pemerintah RI, 2011). Larangan tersebut ternyata kurang diperhatikan.

Pertumbuhan penduduk yang semakin banyak serta bertambahnya laju pembangunan menjadikan penggunaan lahan terus meningkat, ditandai dengan peningkatan kebutuhan tempat tinggal, tetapi tidak diimbangi oleh ketersediaan lahan pemukiman (Nugroho, 2017). Lahan menjadi tempat penunjang keberlangsungan hidup manusia, yaitu: tempat beraktivitas untuk mempertahankan eksistensinya. Apabila terjadi perubahan tata guna lahan di suatu lokasi, maka lahan disekitarnya juga akan beralih fungsi (Putri, 2012).

Perubahan pola penggunaan lahan memberi dampak pada pengurangan kapasitas resapan (Permatasari, 2017), dicirikan dengan berkurang atau bahkan hilangnya vegetasi. Keberadaan vegetasi pada suatu wilayah memberikan dampak positif bagi keseimbangan ekosistem (Naharuddin, 2017), khususnya disekitar sungai.

Vegetasi yang berada di sekitar sungai baik pohon, perdu dan herba disebut dengan vegetasi riparian (Handayani, 2018). Vegetasi tepi sungai atau riparian memiliki fungsi, diantaranya: 1) mengurangi erosi tanah; 2) sebagai penghalang berupa mengurangi sedimen yang masuk ke sungai 3) sebagai peneduh dari sinar matahari agar suhu air tidak berubah demi kelangsungan hidup biota sungai (Junardi, Rafdinal dan Linda, 2018). Hasil observasi lapangan bahwa daerah hulu, tengah dan hilir SubDAS Sungai Gajah Wong telah beralih fungsi menjadi daerah pemukiman dan beberapa telah di talud sehingga membuat jenis tumbuhan yang hidup di sana berkurang yang seharusnya menjadi daerah resapan air dan tempat hidup tumbuhan riparian. Dampak ekologi dari berkurangnya vegetasi riparian dapat terjadinya risiko banjir.

Penelitian oleh Ainy dan Wardhana, (2018) Perubahan pemanfaatan daerah riparian menyebabkan hilangnya kemampuan riparian menahan aliran sungai, dan akibatnya terjadi banjir di hilir, serta punahnya jumlah dan jenis keanekaragaman hayati riparian maupun perairan.

Oleh karena itu, perlu dilakukan penelitian mengenai vegetasi riparian di Sub-DAS Sungai Gajah Wong untuk mengetahui tumbuhan apa saja yang ada di ekosistem riparian serta jenis tanaman untuk konservasi sungai. Tujuan dari penelitian ini adalah untuk mengkaji komposisi, struktur dan keanekaragaman vegetasi riparian yang ada di SubDAS Sungai Gajah Wong, Yogyakarta.

\section{Metode Penelitian}

\subsection{Waktu dan Tempat Penelitian}

Penelitian ini dilaksanakan pada Februari - Juni 2020. Lokasi penelitian terletak bagian hulu, tengah dan hilir di kawasan Sub-DAS Sungai Gajah Wong, Yogyakarta.

Tabel 1. Lokasi Penelitian

\begin{tabular}{ll}
\hline Zona Sungai & \multicolumn{1}{c}{ Lokasi Penelitian } \\
\hline Hulu & Dusun Tanen, Hargobinangun, Kab. Sleman \\
Tengah & Muja Muju, Kecamatan Umbulharjo, Kota \\
& $\begin{array}{l}\text { Yogyakarta } \\
\text { Hilir }\end{array}$ \\
\hline
\end{tabular}

Pengambilan sampel untuk analisis vegetasi menggunakan metode plot kuadrat. Caranya: Ambil garis transek sepanjang $150 \mathrm{~m}$ yang dibagi menjadi tiga plot kuadrat, dengan jarak antar plot 40m. Tiap titik tersebut diletakkan plot kuadrat berukuran $10 \mathrm{~m}$ $\mathrm{x} 10 \mathrm{~m}$ untuk pohon, $5 \mathrm{~m}$ x $5 \mathrm{~m}$ untuk perdu, dan $1 \mathrm{~m} \mathrm{x}$ $1 \mathrm{~m}$ untuk herba. Pada tiap petak kuadrat dilakukan pencatatan yang mencakup nama jenis, jumlah individu, diameter basal area untuk pohon. sedangkan, untuk perdu serta herba dilakukan pencatatan atau pendataan yang mencakup nama jenis, jumlah individu. Metode ini digunakan untuk menggambarkan kondisi vegetasi tumbuhan pada tiap stasiun. Dari setiap stasiun pengamatan diambil sampel vegetasi sesuai fase pertumbuhan vegetasi.

Sampel - sampel yang yang diambil sepanjang transek akan memberikan gambaran yang baik mengenai populasi kawasan tersebut. Data sistem analisis melalui variabel kerapatan, dominansi, dan frekuensi. Data hasil perhitungan tersebut, kemudian diinterpretasikan dalam bentuk tabel untuk menghitung indeks nilai penting dan keanekaragaman. 


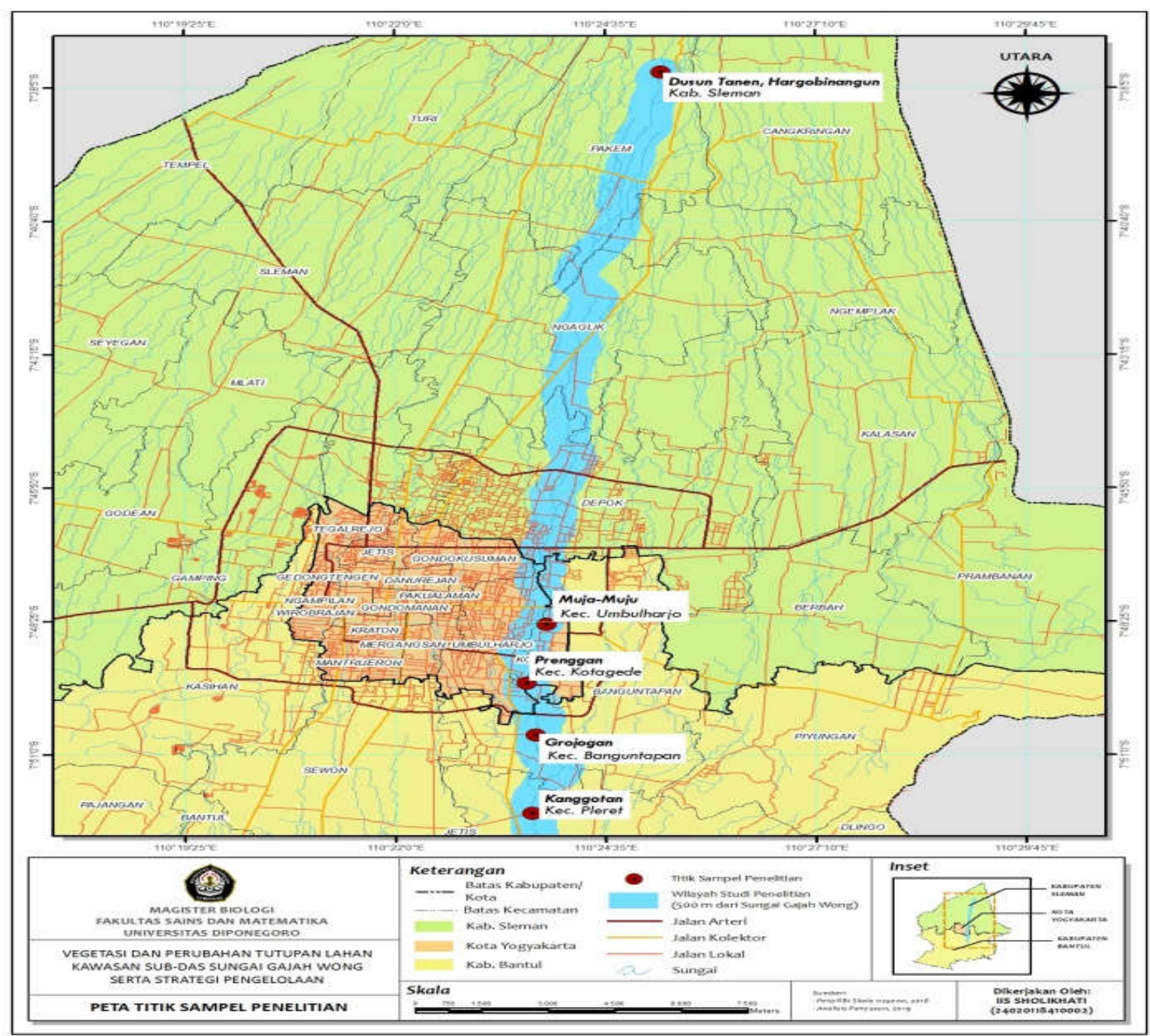

Gambar 1. Peta Sub - DAS Sungai Gajah Wong

Menurut Ifo et al., (2016) Rumus yang digunakan untuk menghitung indeks ini adalah persamaan Shannon-Wiener, sebagai berikut :

$$
\mathrm{H}^{\prime}=\sum_{i=1}^{s} P i \ln P i
$$

Keterangan :

$\mathrm{H}^{\prime}$ = Indeks Keanekaragaman Jenis Shannon Wiener

pi $=$ Proporsi kerapatan jenis $\mathrm{ke}-\mathrm{i}=(\mathrm{ni} / \mathrm{N})$

$\mathrm{ni}=$ Kerapatan jenis ke $-\mathrm{i}$

$\mathrm{N}=$ Jumlah total seluruh jenis

Menurut Mokoginta, (2016) Klasifikasi Indeks Shannon-Wiener, ada tiga kategori keanekaragaman spesies, yaitu :

a) Nilai $\mathrm{H}^{\prime}$ Indeks $>3$ adalah keanekaragaman yang tinggi, jumlah individu yang tinggi di setiap spesies, dan stabilitasnya yang tinggi

b) Nilai $\mathrm{H}^{\prime}$ Indeks 1- 3 adalah keanekaragaman moderat, jumlah individu dalam setiap spesies sedang, dan stabilitasnya sedang

c) Nilai $\mathrm{H}^{\prime}$ Indeks $<1$ adalah keanekaragaman yang rendah, jumlah individu yang rendah pada setiap spesies dan stabilitasnya rendah.

\section{Hasil dan Pembahasan}

Hasil penelitian yang dilakukan di kawasan Sub - DAS Sungai Gajah Wong bagian hulu, tengah dan hilir ditemukan 49 spesies vegetasi riparian. Spesies - spesies yang ditemukan tersebut termasuk dalam famili: Poaceae, Moraceae, Rubiaceae, Gnetaceae, Elaeocarpaceae, Combretaceae, Fabaceae Lamiaceae, Malvaceae, Caricaceae, Phyllanthaceae, Myrtaceae, Arecaceae, Euphorbiaceae, Bromiliacea, Araceae, Solanaceae, Salicaceae, Asteraceae, Pteridaceae, Dryopteridaceae, Commelinaceae, Aspleniaceae, Marsileaceae, Verbenaceae, Musaceae, dan Amaranthaceae.

Spesies tumbuhan yang ditemukan pada habitus pohon dari 13 famili, diantaranya; Famili Poaceae (3 spesies), Moraceae (2 spesies), Fabaceae ( 2 spesies), Rubiaceae, Gnetaceae, Elaeocarpaceae, Combretaceae, Lamiaceae, Malvaceae, Caricaceae, Phyllanthaceae, Myrtaceae dan Musaceae masing masing 1 spesies. Data spesies pohon dalam Famili dapat dilihat pada tabel 2 .

Habitus Perdu terdiri dari 12 Famili, diantaranya: Famili Euphorbiaceae (3 spesies), Fabaceae (2 spesies), Asteraceae (2 spesies), Arecaceae, Rubiaceae, Bromiliaceae, Araceae, 
Solanaceae, Salicaceae, Malvaceae, Araliaceae, dan Lamiaceae masing - masing 1 spesies. Pendistribusian spesies pada habitus perdu dapat dilihat tabel 3, dan untuk habitus herba terdapat 12 Famili diantaranya; Asteraceae 3 spesies, Araceae,
Amaranthaceae masing - masing 2 spesies, Pteridaceae, Dryopteridaceae, Commelinaceae, Aspleniaceae, Marsileaceae, Verbenaceae, Musaceae, Fabaceae, Lamiaceae masing - masing 1 spesies pada tabel

Tabel 2. Daftar Jenis Vegetasi Riparian Pohon di Kawasan Sub-DAS Sungai Gajah Wong, Yogyakarta

\begin{tabular}{|c|c|c|c|c|}
\hline No & Nama Ilmiah & Nama Indonesia & Nama Lokal & Famili \\
\hline 1 & Gigantochloa atroviolacea & Bambu Wulung & Pring Wulung & Poaceae \\
\hline 2 & Bambusa vulgaris & Bambu Kuning & Pring Kuneng & Poaceae \\
\hline 3 & Gigantochloa apus & Bambu Apus & Pring Apus & Poaceae \\
\hline 4 & Artocharpus heterophyllus & Nangka & Nongko & Moraceae \\
\hline 5 & Artocarpus communis & Sukun & Sukun & Moraceae \\
\hline 6 & Coffea robusta & Kopi & Kopi & Rubiaceae \\
\hline 7 & Gnetum gnemon & Melinjo & Mlinjo & Gnetaceae \\
\hline 8 & Muntingia calabura & Kersen & Talok & Elaeocarpaceae \\
\hline 9 & Terminalia catappa & Ketapang & Ketapang & Combretaceae \\
\hline 10 & Tamarindus indica & Asam Jawa & Asem & Fabaceae \\
\hline 11 & Leucaena leucocephala & Petai Cina & Lamtoro & Fabaceae \\
\hline 12 & Tectona grandis & Jati & Jati & Lamiaceae \\
\hline 13 & Hibiscus tiliaceus & Waru & Waru & Malvaceae \\
\hline 14 & Carica papaya & Pepaya & Kates & Caricaceae \\
\hline 15 & Phyllanthus acidus & Ceremai & Cerme & Phyllanthaceae \\
\hline 16 & Psidium guajava & Jambu & Jambu & Myrtaceae \\
\hline 17 & Musa parasidica & Pisang & Gedang & Musaceae \\
\hline
\end{tabular}

Tabel 3. Daftar Jenis Vegetasi Riparian Perdu di Kawasan Sub-DAS Sungai Gajah Wong, Yogyakarta

\begin{tabular}{|c|c|c|c|c|}
\hline No & Nama Ilmiah & Nama Indonesia & Nama Lokal & Famili \\
\hline 1 & Salacca zalacca & Salak & Salak & Arecaceae \\
\hline 2 & Acalypha siamensis & Teh - tehan & Teh - tehan & Euphorbiaceae \\
\hline 3 & Euphorbia heterophylla & Patikan kebo & Patikan kebo & Euphorbiaceae \\
\hline 4 & Acalypha indica & Kucing galak & Anting - anting & Euphorbiaceae \\
\hline 5 & Leucaena leucocephala & Petai cina & Lamtoro & Fabaceae \\
\hline 6 & Mimosa pudica & Putri malu & Kucingan & Fabaceae \\
\hline 7 & Coffea robusta & Kopi & Kopi & Rubiaceae \\
\hline 8 & Ananas comosus & Nanas & Nanas & Bromiliaceae \\
\hline 9 & Aglaonema crispum & Sri rejeki & Sri rejeki & Araceae \\
\hline 10 & Nicotiana tabacum $L$ & Tembakau & Mbako & Solanaceae \\
\hline 11 & Salix aurita $L$ & Dedalu & Gandarusa & Salicaceae \\
\hline 12 & Urena lobata & Pulutan & Pulutan & Malvaceae \\
\hline 13 & Eclipta prostrata & Urang - aring & Urang - aring & Asteraceae \\
\hline 14 & Ageratum conyzoides $L$ & Bandotan & Bandotan & Asteraceae \\
\hline 15 & Polyscias scutellaria & Mangkokan & Mangkokan & Araliaceae \\
\hline 16 & Orthosiphon aristatus & Kumis kucing & Remujung & Lamiaceae \\
\hline
\end{tabular}

Tabel 4. Daftar Jenis Vegetasi Riparian Herba di Kawasan Sub-DAS Sungai Gajah Wong, Yogyakarta

\begin{tabular}{|c|c|c|c|c|}
\hline No & Nama Ilmiah & Nama Indonesia & Nama Lokal & Famili \\
\hline 1 & Adiantum Cuneatum & Paku suplir & Suplir & Pteridaceae \\
\hline 2 & Dryopteris filix & Pakis boston & Pakis boston & Dryopteridaceae \\
\hline 3 & Elephantopus scaber & Tapak Liman & Balagaduk & Asteraceae \\
\hline 4 & Sphagneticola trilobata (L.) & Seruni & Seruni & Asteraceae \\
\hline 5 & Commelina diffusa & Aur-aur & Aur-aur & Commelinaceae \\
\hline 6 & Asplenium adiantum & Paku Coban rondo & Paku Coban rondo & Aspleniaceae \\
\hline 7 & Marsilea crenata & Semanggi & Semanggi & Marsileaceae \\
\hline 8 & Stachytarpheta jamaicensis (L.) & Pecut Kuda & Jarong & Verbenaceae \\
\hline 9 & Colocasia esculenta & Talas & Tales & Araceae \\
\hline 10 & Alocasia macrorrhizos & Bira & Sente & Araceae \\
\hline 11 & Biden pillosa & Ajeran & Ajeran & Asteraceae \\
\hline 12 & Amaranthus viridris & Bayam & Bayem & Amaranthaceae \\
\hline 13 & Gomphrena globosa & Kenop & Adas - adasan & Amaranthaceae \\
\hline 14 & Paseolus vulgaris & Kacang buncis & Buncis & Fabaceae \\
\hline 15 & Menta aquatica $L$ & Mint air & Mint air & Lamiaceae \\
\hline 16 & Phyllanthus urinaria & Meniran & Meniran & Phyllanthaceae \\
\hline
\end{tabular}




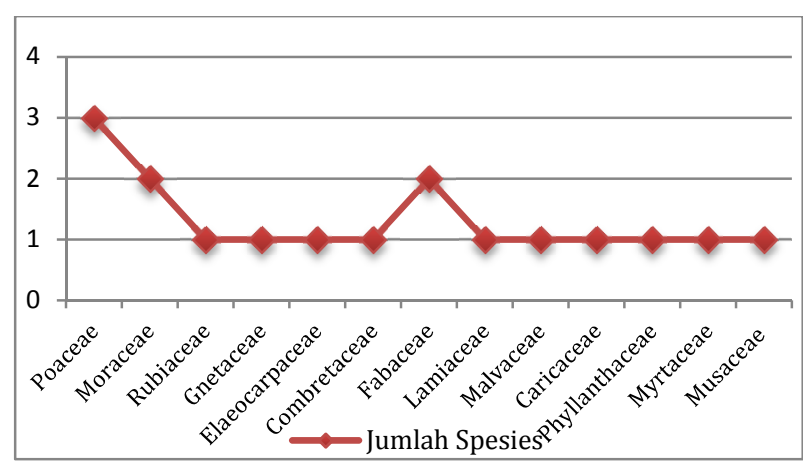

Gambar 2. Diagram Spesies Pohon dalam Famili Berbeda di Kawasan Sub-DAS Sungai Gajah Wong, Yogyakarta

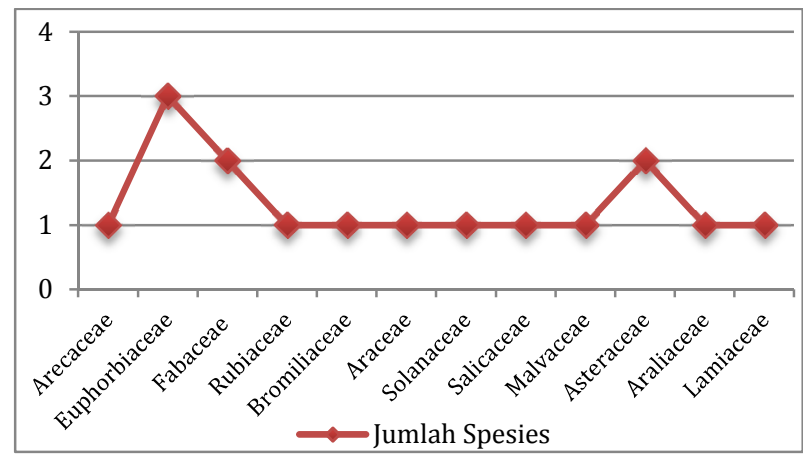

Gambar 3. Diagram Spesies Perdu dalam Famili Berbeda di Kawasan Sub-DAS Sungai Gajah Wong, Yogyakarta

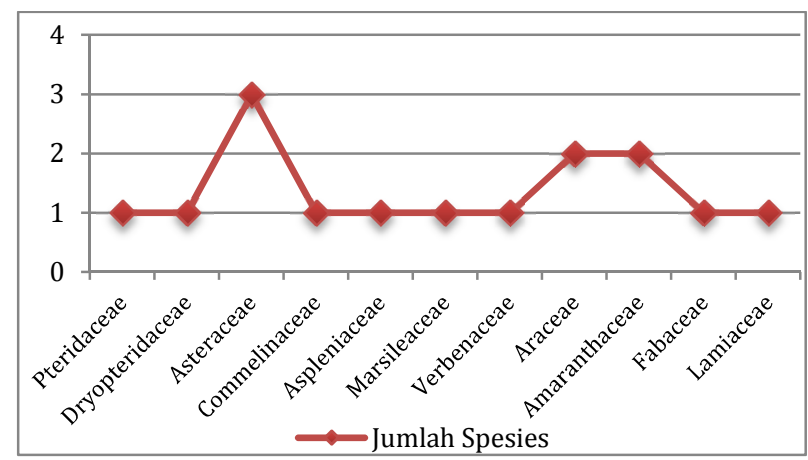

Gambar 4. Diagram Spesies Herba dalam Famili Berbeda di

Kawasan Sub-DAS Sungai Gajah Wong, Yogyakarta

Penyebaran vegetasi daerah hulu, tengah, dan hilir digambarkan dengan Indeks Nilai Penting (INP) dan Indeks Keanekaragaman ( $\left.\mathrm{H}^{\prime}\right)$. INP menunjukkan kepentingan suatu jenis tumbuhan serta peranannya dalam komunitas, dimana nilai penting pada vegetasi tingkat pohon, perdu dan herba didapat dari hasil penjumlahan Kerapatan Relatif (KR), Frekuensi Relatif (FR) dan Dominansi Relatif (DR). Nilai maksimum dari INP adalah 300. (Heddy, 2012). Indeks Nilai Penting (INP) dapat dikategorikan dalam skala 0-300, yaitu pada skala 0-100 termasuk ke dalam kategori rendah, skala 101-200 termasuk ke dalam kategori sedang dan untuk skala 201-300 termasuk kedalam kategori tinggi.

Indeks Nilai Penting Pohon di kawasan Sub DAS Sungai Gajah Wong pada bagian hulu (Dusun Tanen, Hargobinangun, Kecamatan Pakem) menunjukkan bahwa INP tertinggi adalah Bambu wulung atau Gigantochloa atroviolacea (167\%). Daerah tengah (Muja Muju, Kecamatan Umbulharjo, Kota Yogyakarta) INP tertinggi yaitu Lamtoro atau Leucaena leucocephala (118\%), dan Bambusa vulgaris atau Bambu kuning (93\%). Daerah hilir (Kanggotan, Kecamatan Pleret, Kabupaten Bantul) indeks penting tertinggi ditempati oleh Gigantochloa apus atau Bambu apus (102\%). Indeks keanekaragaman spesies pohon di kawasan Sub-DAS Sungai Gajah Wong; Daerah hulu $(0,99)$, tengah $(1,2)$, dan hilir $(1,5)$.

Daerah hulu memiliki indeks keanekaragaman dengan nilai 0,99 merupakan kategori rendah, disebabkan oleh tanaman daerah hulu didominasi dengan frekuensi kehadiran pohon bambu lebih banyak dibandingkan dengan pohon yang lainnya. Masyarakat daerah hulu memanfaatkan bambu sebagai bahan bangunan, sehingga perlu diperhatikan kembali agar tidak menyebabkan eksploitasi atau penyalahgunaan pohon bambu.

Hulu Sub-DAS Sungai Gajah Wong berada di Dusun Tanen, Hargobinangun Kecamatan Pakem yang terletak di kawasan lereng Merapi. Potensi alam yang ditawarkan sangat indah dan memiliki berbagai macam destinasi yang dapat menarik wisatawan, selain itu hawa yang sejuk menimbulkan kesan menarik untuk berkunjung, sehingga memiliki minat dan motif tertentu seperti membangun tempat tinggal (permukiman). Hal tersebut mengakibatkan adanya pemenuhan kebutuhan lahan sebagai tempat tinggal semakin meningkat dan padatnya permukiman; terlihat banyak bangunan penginapan di area hulu Sub-DAS Sungai Gajah Wong. Permukiman di daerah hulu yang padat, menyebabkan daya resapan air berkurang sehingga dapat mendatangkan risiko banjir.

Penelitian ini diperjelas oleh Ardiansyah dan Sumunar, (2020) Interval risiko banjir di Sub-DAS Sungai Gajah Wong terdiri dari tiga interval yaitu interval risiko banjir rendah, interval risiko banjir sedang dan interval risiko banjir tinggi. Distribusi interval risiko banjir tersebut, meliputi : zona hulu, tengah, dan hilir. Interval risiko banjir dengan kriteria rendah hampir tersebar dari seluruh wilayah Kecamatan Pakem, Kecamatan Ngemplak, dan Kecamatan Ngaglik. Interval risiko banjir sedang didistribusikan ke beberapa bagian zona tengah dan hilir yaitu mencakup beberapa Kecamatan Umbulharjo, sebagian Kota Gede dan Kecamatan Banguntapan. Zona dengan interval risiko banjir tinggi terdiri dari dua kecamatan yaitu Kecamatan Depok bagian selatan dan Kecamatan Pleret.

Daerah hulu juga merupakan derah konservasi sehingga masyarakat di daerah hulu lebih banyak menanam pohon bambu dibandingkan dengan tanaman lain. Daerah hulu perlu diperhatikan kembali karena apabila mengalami kerusakan, akan berdampak pada daerah hilirnya. Penanaman bambu di daerah hulu dan sepanjang tepian sungai merupakan langkah yang baik sebagai upaya pengurangan risiko terjadinya banjir. Ketika air 
datang dengan intensitas tinggi, pohon bambu mampu mengkonservasi air. Hal ini diperjelas oleh Noverma, (2017) Bambu menjadi tanaman konservasi air melalui sifat kapiler batang bambu yang dapat menghisap air saat terjadi banjir dan menampung air pada musim kemarau dalam jangka waktu yang lama.

Daerah tengah Sub-DAS Sungai Gajah Wong terletak di Muja Muju, Kecamatan Umbulharjo, Kota Yogyakarta mengalami perubahan alih fungsi lahan. Lahan sekitar Sub-DAS Sungai Gajah Wong yang strategis meningkatkan minat pembangunan sarana maupun prasarana di perkotaan, hal ini menimbulkan vegetasi riparian mengalami penyusutan dan dapat menimbulkan banjir. Upaya pemerintah mengatasnoveri hal tersebut adalah penataan bantaran sungai. Penataan bantaran sungai dengan cara pembuatan talud dan ruang terbuka hijau publik yang diberi nama "Taman Gajah Wong" menjadikan vegetasi alami hilang sehingga digantikan dengan vegetasi baru melalui penanaman kembali (reboisasi), akan tetapi kegiatan reboisasi tersebut belum maksimal dilakukan, maka indeks keanekaragaman spesies tingkat pohon daerah tengah Sub-DAS Sungai Gajah Wong memiliki nilai 1,2 merupakan kategori sedang.

Daerah hilir sungai merupakan daerah tampungan air dari daerah hulu dan tengah. Intensitas risiko terjadinya longsor dan banjir juga tinggi. Daerah hilir juga mengalami perubahan tata guna lahan disepanjang pinggir sungai, akan tetapi perubahan yang terjadi tidak terlalu signifikan seperti pada daerah hulu dan tengah. Penanggulangan mencegah terjadinya banjir dilakukan dengan pembuatan talud di pinggir sungai.
Pembangunan talud ini bertujuan untuk melindungi tebing dari derasnya aliran sungai. Akan tetapi hal tersebut tidak menjamin menghilangkan potensi longsor yang terjadi. Talud atau tanggul sungai dipasang dengan cara menghilangkan vegetasi pada tebing sungai dan memasang tebing sungai berupa struktur beton (Aldhila Gusta H.Y dan Widiyanto, 2016). Hasil inventarisasi memiliki indeks keanekaragaman dengan nilai lebih tinggi dibandingkan hulu dan tengah yaitu dengan nilai indeks keanekaragaman 1,5 (kategori sedang). Hasil inventarisasi lapangan, masyarakat hilir cenderung lebih memilih menanam tanaman budidaya, dibandingkan tanaman konservasi untuk mengurangi risiko terjadinya longsor dan banjir meskipun tingkat dominansi Bambu apus di daerah hilir masih dominan. Tanaman budidaya diantaranya; Pohon cermai, pepaya, pisang, jambu, kersen, sukun, sedangkan tanaman konservasi pada hilir hanya Bambu apus dan Jati.

Vegetasi dominan daerah hulu, tengah, dan hilir adalah tanaman jenis bambu (Gigantochloa atroviolacea, Bambusa vulgaris, dan Gigantochloa apus) dengan famili Poaceae memiliki nilai konservasi untuk ekosistem. Tanaman bambu dari segi ekologis memiliki kemampuan menjaga keseimbangan lingkungan karena sistem perakarannya. Bambu memiliki sistem perakaran yang rapat, luas dan kuat sehingga dapat memperkuat struktur tanah dan mencegah terjadinya erosi (Huzaemah, Mulyaningsih dan Aryanti, 2016; Mentari, Mulyaningsih dan Aryanti, 2018).

Distribusi penyebaran jenis pohon daerah hulu sungai dapat dilihat (tabel 5), daerah tengah sungai (tabel 6), dan hilir sungai (tabel 7).

Tabel 5. Jumlah Jenis Pohon yang ditemukan di Kawasan Sub-DAS Sungai Gajah Wong bagian hulu

\begin{tabular}{|c|c|c|c|c|c|c|c|c|c|}
\hline \multirow{2}{*}{ No } & \multirow{2}{*}{ Nama ilmiah } & \multicolumn{3}{|c|}{ Jumlah (ind/150m²) } & \multirow{2}{*}{$\begin{array}{l}\text { Jumlah } \\
\text { individu }\end{array}$} & \multirow{2}{*}{$\mathbf{K R}$} & \multirow{2}{*}{ FR } & \multirow{2}{*}{ DR } & \multirow{2}{*}{ INP } \\
\hline & & Sta.1 & Sta.2 & Sta.3 & & & & & \\
\hline 1 & Gigantochloa atroviolacea & 39 & 20 & 30 & 89 & $74 \%$ & $20 \%$ & $73 \%$ & $167 \%$ \\
\hline 2 & Artocharpus heterophyllus & 2 & 0 & 4 & 6 & $5 \%$ & $13 \%$ & $6 \%$ & $25 \%$ \\
\hline 3 & Coffea robusta & 3 & 5 & 6 & 14 & $12 \%$ & $20 \%$ & $9 \%$ & $40 \%$ \\
\hline 4 & Gnetum gnemon & 2 & 0 & 0 & 2 & $2 \%$ & $7 \%$ & $1 \%$ & $9 \%$ \\
\hline 5 & Muntingia calabura & 1 & 0 & 2 & 3 & $2 \%$ & $13 \%$ & $1 \%$ & $17 \%$ \\
\hline 6 & Terminalia catappa & 0 & 0 & 1 & 1 & $1 \%$ & $7 \%$ & $1 \%$ & $9 \%$ \\
\hline 7 & Artocarpus communis & 0 & 0 & 1 & 1 & $1 \%$ & $7 \%$ & $1 \%$ & $8 \%$ \\
\hline 8 & Tectona grandis & 0 & 2 & 3 & 5 & $4 \%$ & $13 \%$ & $8 \%$ & $26 \%$ \\
\hline & Jumlah Total & 47 & 27 & 47 & 121 & 100 & $100 \%$ & $100 \%$ & $300 \%$ \\
\hline
\end{tabular}

Tabel 6. Jumlah Jenis Pohon yang ditemukan di Kawasan Sub-DAS Sungai Gajah Wong bagian tengah

\begin{tabular}{|c|c|c|c|c|c|c|c|c|c|}
\hline \multirow{2}{*}{ No } & \multirow{2}{*}{ Nama ilmiah } & \multicolumn{3}{|c|}{ Jumlah (ind/150m²) } & \multirow{2}{*}{$\begin{array}{l}\text { Jumlah } \\
\text { individu }\end{array}$} & \multirow{2}{*}{ KR } & \multirow{2}{*}{ FR } & \multirow{2}{*}{ DR } & \multirow{2}{*}{ INP } \\
\hline & & Sta.1 & Sta.2 & Sta.3 & & & & & \\
\hline 1 & Hibiscus tiliaceus & 0 & 1 & 0 & 1 & $2 \%$ & $14 \%$ & $1 \%$ & $17 \%$ \\
\hline 2 & Tamarindus indica & 0 & 0 & 2 & 2 & $3 \%$ & $14 \%$ & $1 \%$ & $19 \%$ \\
\hline 3 & Leucaena leucocephala & 0 & 4 & 10 & 14 & $23 \%$ & $29 \%$ & $66 \%$ & $118 \%$ \\
\hline 4 & Muntingia calabura & 0 & 0 & 7 & 7 & $11 \%$ & $14 \%$ & $4 \%$ & $30 \%$ \\
\hline 5 & Carica papaya & 3 & 0 & 0 & 3 & $5 \%$ & $14 \%$ & $4 \%$ & $23 \%$ \\
\hline \multirow[t]{2}{*}{6} & Bambusa vulgaris & 0 & 0 & 34 & 34 & $56 \%$ & $14 \%$ & $23 \%$ & $93 \%$ \\
\hline & Jumlah total & 3 & 5 & 53 & 61 & $100 \%$ & $100 \%$ & $100 \%$ & $300 \%$ \\
\hline
\end{tabular}


Tabel 7. Jumlah Jenis Pohon yang ditemukan di Kawasan Sub-DAS Sungai Gajah Wong bagian hilir

\begin{tabular}{|c|c|c|c|c|c|c|c|c|c|}
\hline \multirow{2}{*}{ No } & \multirow{2}{*}{ Nama ilmiah } & \multicolumn{3}{|c|}{ Jumlah (ind/150m²) } & \multirow{2}{*}{$\begin{array}{l}\text { Jumlah } \\
\text { individu }\end{array}$} & \multirow{2}{*}{$\mathbf{K R}$} & \multirow{2}{*}{ FR } & \multirow{2}{*}{ DR } & \multirow{2}{*}{ INP } \\
\hline & & Sta.1 & Sta.2 & Sta.3 & & & & & \\
\hline 1 & Gigantochloa apus & 15 & 0 & 0 & 15 & $56 \%$ & $9 \%$ & $37 \%$ & $102 \%$ \\
\hline 2 & Phyllanthus acidus & 0 & 0 & 1 & 1 & $4 \%$ & $18 \%$ & $4 \%$ & $25 \%$ \\
\hline 3 & Carica papaya & 0 & 3 & 1 & 4 & $15 \%$ & $18 \%$ & $19 \%$ & $52 \%$ \\
\hline 4 & Musa parasidica & 1 & 0 & 0 & 1 & $4 \%$ & $9 \%$ & $7 \%$ & $19 \%$ \\
\hline 5 & Terminalia catappa & 1 & 2 & 0 & 3 & $11 \%$ & $18 \%$ & $20 \%$ & $49 \%$ \\
\hline 6 & Psidium guajava & 0 & 0 & 1 & 1 & $4 \%$ & $9 \%$ & $4 \%$ & $17 \%$ \\
\hline 7 & Muntingia calabura & 0 & 0 & 1 & 1 & $4 \%$ & $9 \%$ & $2 \%$ & $15 \%$ \\
\hline \multirow[t]{2}{*}{8} & Artocarpus communis & 1 & 0 & 0 & 1 & $4 \%$ & $9 \%$ & $8 \%$ & $21 \%$ \\
\hline & Jumlah total & 18 & 5 & 4 & 27 & $100 \%$ & $100 \%$ & $100 \%$ & $300 \%$ \\
\hline
\end{tabular}

Tabel 8. Indeks Keanekaragaman Pohon yang ditemukan di Kawasan Sub-DAS Sungai Gajah Wong

bagian hulu, tengah dan hilir

\begin{tabular}{ccc}
\hline No & Lokasi & H'$^{\prime}$ \\
\hline 1 & Hulu & 0,99 \\
2 & Tengah & 1,2 \\
3 & Hilir & 1,5 \\
\hline
\end{tabular}

Vegetasi tingkat perdu dikawasan Sub-DAS Sungai Gajah Wong yaitu daerah hulu indeks nilai penting ditempati oleh Mimosa pudica (112\%) dengan kategori sedang. Daerah tengah didominasi oleh Urena lobata (84\%) dan Mimosa pudica (71\%) merupakan kategori rendah. Daerah hilir berupa Mimosa pudica dan Acalypha indica (91\%) dengan kategori rendah. Tanaman Mimosa pudica termasuk dalam famili fabaceae biasanya tumbuh secara liar di tepi sungai. Tanaman ini memiliki karakteristik unik yang mudah dikenali, yaitu daun-daunnya dapat secara cepat menutup atau layu dengan sendirinya saat mendapat sentuhan (Karyati dan Adhi, 2018). Putri malu juga memiliki fungsi ekologis yaitu dapat mensuburkan tanah serta akarnya dapat menghancurkan tanah-batuan yang keras (Feriadi dan Frick, 2008). Mimosa pudica atau putri malu ditemukan hampir di setiap daerah Sub - DAS Sungai Gajah Wong, tetapi jumlah yang paling dominan terdapat daerah hulu, karena hulu merupakan daerah konservasi serta dapat menyuburkan tanah di daerah hulu.

Hasil analisis indeks keanekaragaman $\left(\mathrm{H}^{\prime}\right)$ tingkat perdu pada kawasan Sub-DAS Sungai Gajah Wong yaitu pada daerah hulu, tengah dan hilir menunjukkan angka kategori moderat, namun daerah hulu dan tengah memiliki angka indeks yang lebih signifikan dibandingkan dengan daerah hilir sungai. Berdasarkan hasil perhitungan diketahui bahwa angka indeks daerah hulu, tengah dan hilir berturut - turut 1,7, 1,6 dan 1,4. Distribusi penyebaran jenis perdu daerah hulu sungai dapat dilihat (tabel 9), daerah tengah (tabel 10), dan hilir sungai (tabel 11).

Tabel 9. Jenis Perdu yang ditemukan di kawasan Sub-DAS Sungai Gajah Wong bagian hulu

\begin{tabular}{|c|c|c|c|c|c|c|c|c|c|}
\hline \multirow{2}{*}{ No } & \multirow{2}{*}{ Nama ilmiah } & \multicolumn{3}{|c|}{ Jumlah (ind/150m²) } & \multirow{2}{*}{$\begin{array}{l}\text { Jumlah } \\
\text { individu }\end{array}$} & \multirow{2}{*}{ KR } & \multirow{2}{*}{ FR } & \multirow{2}{*}{ DR } & \multirow{2}{*}{ INP } \\
\hline & & Sta.1 & Sta.2 & Sta.3 & & & & & \\
\hline 1 & Salacca zalacca & 1 & 0 & 3 & 4 & $0 \%$ & $13 \%$ & $0 \%$ & $13 \%$ \\
\hline 2 & Acalypha siamensis & 1 & 0 & 0 & 1 & $2,33 \%$ & $7 \%$ & $0,3 \%$ & $9 \%$ \\
\hline 3 & Leucaena leucocephala & 4 & 0 & 3 & 7 & $16,3 \%$ & $13 \%$ & $12 \%$ & $42 \%$ \\
\hline 4 & Mimosa pudica & 5 & 5 & 5 & 15 & $35 \%$ & $20 \%$ & $57 \%$ & $112 \%$ \\
\hline 5 & Coffea robusta & 3 & 0 & 3 & 6 & $13,95 \%$ & $13 \%$ & $9 \%$ & $36 \%$ \\
\hline 6 & Ananas comosus & 2 & 0 & 6 & 8 & $19 \%$ & $13 \%$ & $16 \%$ & $48 \%$ \\
\hline 7 & Aglaonema crispum & 0 & 2 & 0 & 2 & $5 \%$ & $7 \%$ & $1 \%$ & $12 \%$ \\
\hline \multirow[t]{2}{*}{8} & Nicotiana tabacum $L$ & 0 & 1 & 3 & 4 & $9,3 \%$ & $13 \%$ & $4 \%$ & $27 \%$ \\
\hline & Jumlah total & 16 & 8 & 23 & 47 & $100 \%$ & $100 \%$ & $100 \%$ & $300 \%$ \\
\hline
\end{tabular}

Tabel 10. Jenis Perdu yang ditemukan di kawasan Sub-DAS Sungai Gajah Wong bagian tengah

\begin{tabular}{|c|c|c|c|c|c|c|c|c|c|}
\hline \multirow{2}{*}{ No } & \multirow{2}{*}{ Nama ilmiah } & \multicolumn{3}{|c|}{ Jumlah (ind/150m²) } & \multirow{2}{*}{$\begin{array}{l}\text { Jumlah } \\
\text { individu }\end{array}$} & \multirow{2}{*}{ KR } & \multirow{2}{*}{ FR } & \multirow{2}{*}{ DR } & \multirow{2}{*}{ INP } \\
\hline & & Sta.1 & Sta.2 & Sta.3 & & & & & \\
\hline 1 & Salix aurita $L$ & 23 & 34 & 0 & 57 & $22 \%$ & $17 \%$ & $23 \%$ & $61 \%$ \\
\hline 2 & Urena lobata & 17 & 57 & 0 & 74 & $28 \%$ & $17 \%$ & $38 \%$ & $84 \%$ \\
\hline 3 & Mimosa pudica & 23 & 30 & 5 & 58 & $22 \%$ & $25 \%$ & $24 \%$ & $71 \%$ \\
\hline 4 & Euphorbia heterophylla & 13 & 24 & 0 & 37 & $14 \%$ & $17 \%$ & $10 \%$ & $41 \%$ \\
\hline 5 & Eclipta prostrata & 7 & 0 & 0 & 7 & $3 \%$ & $8 \%$ & $0 \%$ & $11 \%$ \\
\hline \multirow[t]{2}{*}{6} & Ageratum conyzoides $L$ & 6 & 21 & 0 & 27 & $10 \%$ & $17 \%$ & $5 \%$ & $32 \%$ \\
\hline & Jumlah total & 89 & 166 & 5 & 260 & $100 \%$ & $100 \%$ & $100 \%$ & $300 \%$ \\
\hline
\end{tabular}


Tabel 11. Jenis Perdu yang ditemukan di kawasan Sub-DAS Sungai Gajah Wong bagian hilir

\begin{tabular}{|c|c|c|c|c|c|c|c|c|c|}
\hline \multirow{2}{*}{ No } & \multirow{2}{*}{ Nama ilmiah } & \multicolumn{3}{|c|}{ Jumlah (ind/150m²) } & \multirow{2}{*}{$\begin{array}{l}\text { Jumlah } \\
\text { individu }\end{array}$} & \multirow{2}{*}{ KR } & \multirow{2}{*}{ FR } & \multirow{2}{*}{ DR } & \multirow{2}{*}{ INP } \\
\hline & & Sta.1 & Sta.2 & Sta.3 & & & & & \\
\hline 1 & Polyscias scutellaria & 0 & 8 & 1 & 9 & $21 \%$ & $25 \%$ & $17 \%$ & $63 \%$ \\
\hline 2 & Leucaena leucocephala & 1 & 0 & 0 & 1 & $2 \%$ & $13 \%$ & $0 \%$ & $15 \%$ \\
\hline 3 & Orthosiphon aristatus & 0 & 7 & 0 & 7 & $16 \%$ & $13 \%$ & $10 \%$ & $39 \%$ \\
\hline 4 & Mimosa pudica & 0 & 11 & 2 & 13 & $30 \%$ & $25 \%$ & $36 \%$ & $91 \%$ \\
\hline \multirow[t]{2}{*}{5} & Acalypha indica & 0 & 9 & 4 & 13 & $30 \%$ & $25 \%$ & $36 \%$ & $91 \%$ \\
\hline & Jumlah total & 1 & 35 & 7 & 43 & $100 \%$ & $100 \%$ & $100 \%$ & $300 \%$ \\
\hline
\end{tabular}

Tabel 12. Indeks Keanekaragaman Perdu yang ditemukan di Kawasan Sub-DAS Sungai Gajah Wong bagian hulu, tengah dan hilir

\begin{tabular}{ccc}
\hline No & Lokasi & H'$^{\prime}$ \\
\hline 1 & Hulu & 1,7 \\
2 & Tengah & 1,6 \\
3 & Hilir & 1,4 \\
\hline
\end{tabular}

Penyebaran vegetasi tingkat herba dikawasan Sub-DAS Sungai Gajah Wong hulu, tengah dan hilir jumlah KR (\%), FR (\%), dan INP terbesar ditempati oleh Commelina diffusa, Menta aquatica $L$ dan Cyperus Rotundus. Kerapatan Relatif menunjukkan jumlah individu yang menjadi suatu komunitas tumbuhan dalam areal penelitian, sedangkan Frekuensi Relatif merupakan perbandingan antara frekuensi mutlak suatu jenis dengan frekuensi total seluruh jenis pada seluruh areal penelitian. Frekuensi kehadiran suatu jenis organisme di suatu habitat menunjukkan keseringhadiran spesies tersebut di habitatnya.

Commelina diffusa, Menta aquatica $L$ dan Cyperus Rotundus memiliki nilai kerapatan relatif tinggi dikarenakan memiliki jumlah individu paling banyak dalam suatu lokasi penelitian per satuan luas lokasi tersebut, serta terdapat frekuensi kehadiran yang hampir merata pada setiap stasiun penelitian. INP dari ketiga spesies tersebut berturut-turut : $57 \%$ (hulu), 67\% (tengah), dan 55\% (hilir) dan Hasil analisis indeks keanekaragaman $\left(\mathrm{H}^{\prime}\right)$ tingkat herba di kawasan Sub - DAS Sungai Gajah Wong menunjukkan angka kategori moderat yaitu hulu $(2)$, tengah $(1,4)$ dan hilir (2).

Daerah hulu dan hilir memiliki angka indeks yang lebih signifikan dibanding daerah tengah. Jenis herba pada daerah hulu dan hilir lebih beranekaragam. Daerah tengah lebih banyak mengalami perubahan tata guna lahan yang mengakibatkan keberadaan vegetasi menyusut bahkan menghilang dan hanya beberapa spesies tertentu saja yang memiliki kehadiran tertinggi yaitu Menta aquatica $L$.

Commelina diffusa, Menta aquatica $L$ dan Cyperus Rotundus merupakan tanaman yang dianggap masyarakat sebagai tanaman pengganggu atau gulma. Distribusi penyebaran jenis herba daerah hulu sungai dapat dilihat (tabel 13), daerah tengah (tabel 14), dan hilir sungai (tabel 15).

Tabel 13. Jumlah Jenis herba yang ditemukan di Kawasan Sub-DAS Sungai Gajah Wong bagian hulu

\begin{tabular}{|c|c|c|c|c|c|c|c|c|}
\hline \multirow{2}{*}{ No } & \multirow{2}{*}{ Nama ilmiah } & \multicolumn{3}{|c|}{ Jumlah (ind/150m²) } & \multirow{2}{*}{$\begin{array}{l}\text { Jumlah } \\
\text { individu }\end{array}$} & \multirow{2}{*}{$\mathbf{K R}$} & \multirow{2}{*}{ FR } & \multirow{2}{*}{ INP } \\
\hline & & Sta.1 & Sta.2 & Sta.3 & & & & \\
\hline 1 & Adiantum Cuneatum & 6 & 0 & 0 & 6 & $14 \%$ & $11 \%$ & $25 \%$ \\
\hline 2 & Dryopteris filix & 3 & 0 & 0 & 3 & $7 \%$ & $11 \%$ & $18 \%$ \\
\hline 3 & Elephantopus scaber & 1 & 0 & 0 & 1 & $2 \%$ & $11 \%$ & $13 \%$ \\
\hline 4 & Commelina diffusa & 0 & 10 & 5 & 15 & $35 \%$ & $22 \%$ & $57 \%$ \\
\hline 5 & Asplenium adiantum & 0 & 3 & 0 & 3 & $7 \%$ & $11 \%$ & $18 \%$ \\
\hline 6 & Marsilea crenata & 0 & 3 & 0 & 3 & $7 \%$ & $11 \%$ & $18 \%$ \\
\hline 7 & Stachytarpheta jamaicensis (L.) & 0 & 5 & 0 & 5 & $12 \%$ & $11 \%$ & $23 \%$ \\
\hline \multirow[t]{2}{*}{8} & Colocasia esculenta & 0 & 7 & 0 & 7 & $16 \%$ & $11 \%$ & $27 \%$ \\
\hline & Jumlah total & 10 & 21 & 5 & 36 & $100 \%$ & $100 \%$ & $200 \%$ \\
\hline
\end{tabular}

Tabel 14. Jumlah Jenis herba yang ditemukan di Kawasan Sub-DAS Sungai Gajah Wong bagian tengah

\begin{tabular}{|c|c|c|c|c|c|c|c|c|}
\hline \multirow{2}{*}{ No } & \multirow{2}{*}{ Nama ilmiah } & \multicolumn{3}{|c|}{ Jumlah (ind/150m²) } & \multirow{2}{*}{$\begin{array}{l}\text { Jumlah } \\
\text { individu }\end{array}$} & \multirow{2}{*}{$\mathbf{K R}$} & \multirow{2}{*}{ FR } & \multirow{2}{*}{ INP } \\
\hline & & Sta.1 & Sta.2 & Sta.3 & & & & \\
\hline 1 & Biden pillosa & 0 & 0 & 5 & 5 & $3 \%$ & $13 \%$ & $16 \%$ \\
\hline 2 & Amaranthus viridris & 0 & 0 & 4 & 4 & $3 \%$ & $13 \%$ & $15 \%$ \\
\hline 3 & Paseolus vulgaris & 0 & 0 & 46 & 46 & $31 \%$ & $13 \%$ & $44 \%$ \\
\hline 4 & Menta aquatica $L$ & 25 & 37 & 0 & 62 & $42 \%$ & $25 \%$ & $67 \%$ \\
\hline 5 & Sphagneticola trilobata (L.) & 13 & 9 & 0 & 22 & $15 \%$ & $25 \%$ & $40 \%$ \\
\hline \multirow[t]{2}{*}{6} & Alocasia macrorrhizos & 0 & 0 & 8 & 8 & $5 \%$ & $13 \%$ & $18 \%$ \\
\hline & Jumlah total & 38 & 46 & 63 & 147 & $100 \%$ & $100 \%$ & $200 \%$ \\
\hline
\end{tabular}


Tabel 15. Jumlah Jenis herba yang ditemukan di Kawasan Sub-DAS Sungai Gajah Wong bagian hilir

\begin{tabular}{|c|c|c|c|c|c|c|c|c|}
\hline \multirow{2}{*}{ No } & \multirow{2}{*}{ Nama ilmiah } & \multicolumn{3}{|c|}{ Jumlah (ind/150m²) } & \multirow{2}{*}{$\begin{array}{c}\text { Jumlah } \\
\text { individu }\end{array}$} & \multirow{2}{*}{ KR } & \multirow{2}{*}{ FR } & \multirow{2}{*}{ INP } \\
\hline & & Sta.1 & Sta.2 & Sta.3 & & & & \\
\hline 1 & Biden pillosa & 0 & 0 & 5 & 5 & $6 \%$ & $9 \%$ & $15 \%$ \\
\hline 2 & Amaranthus viridris & 11 & 0 & 3 & 14 & $16 \%$ & $18 \%$ & $34 \%$ \\
\hline 3 & Cyperus Rotundus & 7 & 16 & 9 & 32 & $37 \%$ & $18 \%$ & $55 \%$ \\
\hline 4 & Marselia crenata & 0 & 5 & 0 & 5 & $6 \%$ & $9 \%$ & $15 \%$ \\
\hline 5 & Alocasia acuminate & 0 & 3 & 7 & 10 & $11 \%$ & $18 \%$ & $30 \%$ \\
\hline 6 & Gomphrena globosa & 0 & 7 & 0 & 7 & $8 \%$ & $9 \%$ & $17 \%$ \\
\hline \multirow[t]{2}{*}{7} & Phyllanthus urinaria & 5 & 9 & 0 & 14 & $16 \%$ & $18 \%$ & $34 \%$ \\
\hline & Jumlah total & 23 & 40 & 24 & 87 & $100 \%$ & $100 \%$ & $200 \%$ \\
\hline
\end{tabular}

Tabel 16. Indeks Keanekaragaman herba yang ditemukan di Kawasan Sub-DAS Sungai Gajah Wong bagian hulu, tengah dan hilir

\begin{tabular}{ccc}
\hline No & Lokasi & H'$^{\prime}$ \\
\hline 1 & Hulu & 2 \\
2 & Tengah & 1,4 \\
3 & Hilir & 2 \\
\hline
\end{tabular}

\section{Kesimpulan}

Komposisi vegetasi di Kawasan Sub-DAS Sungai Gajah Wong tercatat terdapat 49 spesies vegetasi riparian hulu, tengah dan hilir. Spesies tumbuhan yang ditemukan pada habitus pohon terdiri dari 13 famili, diantaranya; Famili Poaceae (3 spesies), Moraceae (2 spesies), Fabaceae (2 spesies), Rubiaceae, Gnetaceae, Elaeocarpaceae, Combretaceae, Lamiaceae, Malvaceae, Caricaceae, Phyllanthaceae, Myrtaceae dan Musaceae masing masing 1 spesies. Habitus Perdu terdiri dari 12 Famili, diantaranya: Famili Euphorbiaceae (3 spesies), Fabaceae (2 spesies), Asteraceae (2 spesies), Arecaceae, Rubiaceae, Bromiliaceae, Araceae, Solanaceae, Salicaceae, Malvaceae, Araliaceae, dan Lamiaceae masing - masing 1 spesies dan untuk habitus herba terdapat 12 Famili diantaranya; Asteraceae 3 spesies, Araceae, Amaranthaceae masing - masing 2 spesies, Pteridaceae, Dryopteridaceae, Commelinaceae, Aspleniaceae, Marsileaceae, Verbenaceae, Musaceae, Fabaceae, Lamiaceae masing - masing 1 spesies.

Vegetasi tingkat pohon dengan INP tertinggi daerah hulu Gigantochloa atroviolacea (167\%). Daerah tengah INP tertinggi Leucaena leucocephala (118\%), dan Bambusa vulgaris (93\%). Daerah hilir indeks penting tertinggi ditempati oleh Gigantochloa apus (102\%). Indeks keanekaragaman spesies pohon di kawasan Sub-DAS Sungai Gajah Wong; Daerah hulu $(0,99)$, tengah $(1,2)$, dan hilir $(1,5)$. Tanaman bambu dari segi ekologis memiliki kemampuan menjaga keseimbangan lingkungan karena sistem perakarannya, dapat dikatakan Bambu merupakan tanaman konservasi.

Vegetasi tingkat perdu dikawasan Sub-DAS Sungai Gajah Wong yaitu daerah hulu indeks nilai penting ditempati oleh Mimosa pudica (112\%) dengan kategori sedang. Daerah tengah didominasi oleh Urena lobata (84\%) dan Mimosa pudica (71\%) merupakan kategori rendah. Daerah hilir berupa Mimosa pudica dan Acalypha indica (91\%).

Mimosa pudica ditemukan hampir di setiap daerah Sub - DAS Sungai Gajah Wong yang memiliki fungsi ekologis dapat mensuburkan tanah serta akarnya dapat menghancurkan tanah-batuan yang keras. Hasil analisis indeks keanekaragaman $\left(\mathrm{H}^{\prime}\right)$ tingkat perdu pada kawasan Sub-DAS Sungai Gajah Wong yaitu pada daerah hulu, tengah dan hilir menunjukkan angka kategori moderat, namun daerah hulu dan tengah memiliki angka indeks yang lebih signifikan dibandingkan dengan daerah hilir sungai. Berdasarkan hasil perhitungan diketahui bahwa angka indeks daerah hulu, tengah dan hilir berturut - turut 1,7, 1,6 dan 1,4.

Vegetasi tingkat herba dikawasan Sub-DAS Sungai Gajah Wong hulu, tengah dan hilir INP terbesar ditempati oleh Commelina diffusa (57\%), Menta aquatica $L$ (67\%) dan Cyperus Rotundus (55\%). Masyarakat kawasan Sub-DAS Gajah Wong menganggap ketiga herba tersebut sebagai tanaman pengganggu atau gulma. Hasil analisis indeks keanekaragaman $\left(\mathrm{H}^{\prime}\right)$ tingkat herba di kawasan Sub DAS Sungai Gajah Wong menunjukkan angka kategori moderat yaitu hulu $(2)$, tengah $(1,4)$ dan hilir (2).

Perbedaan indeks keanekaragaman ( $\left.\mathrm{H}^{\prime}\right)$ habitus pohon, perdu dan herba disebabkan oleh berkurang bahkan menghilangnya vegetasi akibat perubahan lahan.

\section{DAFTAR PUSTAKA}

Ainy, N. S. dan Wardhana, W. (2018). Struktur Vegetasi Riparian Sungai Pesanggrahan Kelurahan Lebak Bulus Jakarta Selatan. BIOMA, 14(2), hal. 60-69. doi: 10.21009

Aldhila Gusta H.Y dan Widiyanto. (2016). Kajian Kerawanan Longsor Tebing Sungai Code Daerah Istimewa Yogyakarta (Studi Kasus: Penggal Sungai Code Antara Banteng-Gondolayu). Jurnal Bumi Indonesia, 5(2), 1-10.

Ardiansyah, A. dan Sumunar, D. R. S.. (2020). Flood Vulnerability Mapping Using Geographic Information System ( GIS ) in Gajah Wong Sub Watershed Yogyakarta. GEOSFERA INDONESIA, 5(1), hal. 47-64. doi: 10.19184/geosi.v5i1.9959.

BPS. (2017). Provinsi DAERAH ISTIMEWA YOGYAKARTA 
DALAM ANGKA. Yogyakarta: Badan Pusat Statistik Propinsi D.I.Yogyakarta.pp. 1-510

Djumanto. (2013). Index Biotic Family as Water Quality Indicator. Jurnal Perikanan, XV(1), 26-34.

Feriadi, H. dan Frick, H.. (2008). Atap bertanaman ekologis dan fungsional. Yogyakarta: Kanisius, pp.53

Handayani,P. (2018). Keanekaragaman Vegetasi Riparian Sungai Tabir Desa Sungai Tabir Kecamatan Tabir Barat. Jurnal Pendidikan Biologi dan Biosains, 1(1), 21-27.

Heddy, S.. (2012). Metode Analisis Vegetasi dan Komunitas. Jakarta: Rajawali Pers, pp. 105

Huzaemah, Mulyaningsih, T. dan Aryanti, E. (2016). Identifikasi Bambu pada Daerah Aliran Sungai Tiupupus Kabupaten Lombok Utara. Jurnal Biologi Tropis, 16(2), 23-36.

Ifo, S. A. et al. (2016). Tree Species Diversity, Richness, and Similarity in Intact and Degraded Forest in the Tropical Rainforest of the Congo Basin: Case of the Forest of Likouala in the Republic of Congo. Hindawi Publishing Coporation International Journal of Forestry Research, 1-12. doi: http:/dx.doi.org/10.1155/2016/7593681.

Junardi, I. T., Rafdinal dan Linda, R. (2018). Komposisi Dan Struktur Vegetasi Riparian Di Kawasan Taman Wisata Gunung Poteng Singkawang Kalimantan Barat. Protobiont, 7(3), 118-126.

Karyati dan Adhi, M. A. (2018). Jenis-jenis Tumbuhan Bawah di Hutan Pendidikan Fakultas Kehutanan Universitas Mulawarman. Samarinda: Mulawarman University Press, pp. 103

Mentari, M., Mulyaningsih, T. dan Aryanti, E. (2018). Identifikasi Bambu di Sub Daerah Aliran Sungai
Kedome Lombok Timur dan Alternatif Manfaat untuk Konservasi Sempadan Sungai. JPPDAS, (October), 111-122. doi: 10.20886/jppdas.2018.2.2.111-122.

Mokoginta, M. M. (2016). Tree Species Diversity at the Protected Forest of Mountain Masinggi, North Bolaang Mongondow, Indonesia. International Journal of Agriculture and Forestry, 6(2), 69-73. doi: 10.5923/j.ijaf.20160602.02.

Naharuddin. (2017). Komposisi dan Struktur Vegetasi dalam Potensinya sebagai Parameter Hidrologi dan Erosi. Jurnal Hutan Tropis, 5(2), 6-12.

Noverma. (2017). Peranan Bambu dalam Mendukung Pembangunan Wilayah yang Berkelanjutan. Konferensi Nasional Teknik Sipil 11, 26-27.

Nugroho, A., (2017). Analisis Kerapatan Vegetasi di Kecamatan Ngaglik Tahun 2006 dan 2016 Menggunakan Teknik Penginderaan Jauh, GeoEducasia, 3(2), 306-320.

Peraturan Pemerintah RI., (2011). "Peraturan Pemerintah RI Nomor 38 Tahun 2011." Tersedia pada: http://ditjenpp.kemenkumham.go.id/arsip/ln/2011/ pp38-2011.pdf.

Permatasari, R., (2017). Pengaruh Perubahan Penggunaan Lahan terhadap Rezim Hidrologi DAS (Studi Kasus: DAS Komering). Jurnal Teknik Sipil, 24(1), 91-98. doi: 10.5614/jts.2017.24.1.11.

Putri, A. P., (2012). Pengaruh Perubahan Pola Tata Guna Lahan terhadap Sedimentasi di Hulu Sungai Ular. Jurnal Teknik Sipil USU, 1(2),1-10.

Sriyono, E., dan Kresnanto, N. C. (2017). Analisis Pencemaran Air Sumur di Daerah Berteras Bantaran. Seminar Nasional Teknik Sipil, 1-9. 